\title{
Theoretical and Normative Foundation of Child Rights ${ }^{*}$
}

\author{
Uchenna Emelonye \\ Office of the United Nations High Commissioner for Human Rights, Liberia
}

\begin{abstract}
Based on the conceptual appreciation of human rights as explicitly normative, this paper sets out the philosophical and normative foundation of human rights as a basis for extrapolating the philosophical and normative foundation of child rights. It views human rights as those broadly recognized fundamental global standards of morality that inhere in human beings by virtue of their humanity and which are normatively instituted. Predicated on the argument that child rights share a philosophical heritage with human rights, child rights are construed to be those rights that are normatively established and are specifically and affirmatively applicable to children because of their age, level of mental development, inherent vulnerability, and mitigated culpability.
\end{abstract}

Keywords: child rights, juvenile justice, theory, foundation

\section{Philosophical Foundation of Child Rights}

The philosophical foundation of child rights is very contestable. Langlois’s (2009; 2002) postulated that there are several philosophical foundations of human rights which could be stretched to apply to the philosophical foundation of child rights. Although the classical philosophical divides of human rights may not specifically speak to child rights, the latter could be extrapolated from the general philosophical foundations of human rights. There is no gainsaying the fact that since child rights are an integral component of human rights, the philosophical foundation of child rights is essentially linked to the broad philosophical foundation of human rights (Bunch, 1990; Binion, 1995).

There are several philosophical foundations of law that present distinct and most times interrelated heritage of human rights. They include the natural law, positive law, sociological, Marxism, realism, utilitarianism, and historical and anthropological foundations. While all of these theoretical foundations have bearing on the conception of law in general and human rights in particular, they are not uniformly relevant to the universalist conception of child rights. Consequently, this paper will not explore all the available theoretical foundations of human rights but will focus on those deemed very useful in extrapolating the theoretical foundation of child rights and also essential in illuminating and contextualizing the philosophical preferences of this paper. ${ }^{1}$

\section{Natural Law}

There are various strands of natural law with their theoretical underpinning based on the existence of a

\footnotetext{
Acknowledgement: This paper is written in a personal capacity and does not represent the views of the United Nations.

Uchenna Emelonye, Dr., country representative, Office of the United Nations High Commissioner for Human Rights, Liberia.

1 This article excludes the review of the historical and anthropological foundations of human rights because they are amongst other things based on the inner conscience of the people and somewhat opposed to the universal application of human rights in general and child rights in particular.
} 
"higher law" derived from divine nature as a scale for measuring its validity. The crux of natural law is that law must be propelled by morality. Whilst Blackstone states that "no human laws are of any validity, if contrary to the law of nature” (Blackstone, 1978; Nolan, 1976, p. 731), Bix (2000; 2001) argued that natural law is not susceptible to changes due to the passage of time and its standards are uniformly accessible by resort to reason.

According to Bix (2001), one of the renowned ancient writers on natural law is Cicero. He provided an elegant restatement of already established Stoic views that true law is right reason in agreement with nature, universal in application, unchanging, and everlasting. Thomas Aquinas has also been lauded as one of the most influential writers on natural law (Lisska, 1996). While classifying law into natural, eternal, and divine, and calling for outright disobedience to unjust laws, Lisska recounted Aquinas as stating that positive law inheres from natural law because the latter is the guiding framework for the promulgation and legitimacy of the former (Lisska, 1996).

Natural law theory was later anchored in natural rights, deepened international law debate and appears to have played a significant role in the constitutions of several countries and the modern civil rights movement (Dyson, 2002). On the other hand, Hugo Grotius and Samuel Pufendorf have been identified as prominent examples of theorists whose writings on natural law had significance in the grounding of human rights on natural rights (Waldron, 1989). The natural rights approach was further synthesized by Thomas Hobbes, Jean-Jacques Rousseau, and John Locke into the "social contract" theories (Hampton, 1986, p. 6).

Commenting on the social contract theories, Laslett argues that Locke visualized the existence of human beings in the state of nature where human beings are accorded freedom and equality, are not subjected to the will of another and are able to determine their actions (Locke, 1988). Accordingly, there arose a need to dispense with the hazards and inconveniences of nature in which case a social contract was entered into whereby men mutually agreed to form a community with ground rules (Tully, 1996). Another leading voice in the natural law school is Beitz. Acknowledged for his hybrid alternative to Locke's theory, he argues that the source of human rights is not the law of God but rather the quest for social justice (Beitz, 2001; 2009).

Criticizing Locke's social contract theory, Freeman cited Grotius who is also a protagonist of natural law theory as characterizing human beings as possessing the social impulse to coexist harmoniously with one another (Freeman, 1994; 2011). He also cited Thomas Hobbes and argued that the latter sought to justify natural law not as a derivative of the law of God but as law ordained on the basis of humanity (Freeman, 1994; 2011). On the other hand, Edmund Burke furthered the opposition to Locke's postulation when he argued that "men" and by extension children had rights that are not derivable from the state but originating from the “organic tradition and institutions of the society" (Burke, 2000, p. 40).

The works of the early theorists on natural law understandably differ from the contemporary discourse of natural law (Bix, 1993; 2001; 2003). Finnis's contemporary writings on the nexus between natural law and natural rights have been secular, emphasizing "the requirements of reason rather than divine command, purpose, will, or wisdom” (Finnis, 1988, p. 227; 2000, p. 75; 2011; 2007, p. 315). Writing in a similar tone to Aquinas, Finnis founded his claim on "self-evident basic goods" which he described as things one values for their own sake. Negating positive law as a single-track authority where orders are originated from government as a sole source, Fuller (1958) called for a certain condition precedent before a rule could in its true sense be titled as law. He proposed complementarity and co-operation between government and citizens so that rules must meet certain criteria to earn the title law. He also substituted a positive law analysis of law based on power, orders, and obedience for analysis based on the "internal morality" of law (Fuller, 1958, p. 630; 1969). 
Contrasted to natural law theorists, Fuller's theory is based on process and function rather than strictly on moral content. Similarly, Dworkin (1978; 1986; 2006) challenged positive law and offered an alternative vision of law in which there are abundant resources for resolving disputes "according to law". Several other contemporary writers have contributed to the literature on natural law. They include Michael S. Moore (1985; 2011), Lloyd Weinreb (1987; Bix, 2009), Ernest Weinrib (1988; 2012), Deryck Beyleveld and Roger Brownsword (1983), and Mark Murphy (2001; 2003; 2006). These series of scholarships on natural law do not expressly allude to child rights except through an expansive reading of "people" to include children (Doernberg, 1985, p. 52). As such, in a deductive sense, the natural law theory construes child rights as those inherent ingredients of human dignity held universally and equally by children because of their membership in the human race in the first place and because of their age in the second instance.

As a vocal apostle of the natural law school, Locke's writings infer that natural rights which by deductive inference include child rights are synonymous with natural law and founded on the basis of the law of God (Leyden, 1956; Lenz, 1956). The social contract theory of Locke which by extension supports the natural law conception of child rights may be appropriate in the circumstance of its enunciation. However, situating this theory in the contemporary era would conflict with emerging child rights claims based on the elasticity of present day human needs.

Natural law's age-long conception of human rights made no mention of child rights specifically. Also, contemporary scholars, such as Finnis, Freeman, and Langlois also omitted any reference to child rights in their discourse of the conception of the philosophical foundation of natural law. While Langlois (2009) interpreted human rights as natural rights possessed by men by virtue of their humanity and held universally and equally by all people, Freeman (1994) opined that human rights are held against the whole world, essential to the maintenance of human dignity and ultimately inevitable for the realization of human worth.

The different shades of natural law theory and the strains of its philosophers notwithstanding, it emphasizes the basis for the protection of human rights, including child rights, equality and freedom, and the presupposition of a value transcendental to the naked power of the state and one of the propelling forces behind the growth of the contemporary child rights regime (Shestack, 1998; Mahoney, 2007).

\section{Positive Law}

There is apparently no unitary strand of positive law as disagreements exist within the same theory. Its prominent adherents include important 19th century philosophers, such as John Austin, as well as 20th century thinkers, such as Hans Kelsen (Tamanaha, 2007; Bix, 1999), H. L. A. Hart (1983; 2012), and Joseph Raz (1979; 1985; 2006). Hart (1983; 2012) argued that the central tenet of positive law is the difference between the way the law is and the way it ought to be and its validity as a norm is not necessarily linked to its moral value (Green, 2008). Positive law is opposed to the natural law theory because of their respective interpretation of the concepts of legality and authority (Coleman \& Leiter, 2010; Leiter, 2001).

While not disagreeing on a possible overlap between law and morality, it has been argued that positive law dispenses with the need for moral validity of a norm (Coleman, 1999; Culver, 2001). Coleman and Leiter (2010, p. 228) called this "negative positivism" and state that the mutually reinforcing convergence of law and morality should be the ultimate aspiration of law. On the other hand, since the threat of sanction accounts for the normativity of law and compels citizens to obey the law, the legality of a law under positive law is a function of its source and not dependent on the merits of its substantive provisions (Gardner, 2001). Gardener 
(2001) further argued that the existence of the law is one thing and its merit or demerit is another. As such, law is the order of a sovereign backed by a threat of sanction in the event of non-compliance.

In that case, positive law emphasizes the "source" and not the "merit" of the law such that the validity of the law depends on its source (Spaak, 2003, p. 469; Schauer, 2011, p. 455). It therefore follows that the validity of the law is not subject to the morality of the law and it is immaterial that such a norm would have been an excellent norm if adopted. Positive law entrusts upon the state the mandate to institutionalize what is considered "right" or "wrong" and establish a legal regime separate from the moral foundation of society. It validates legal obligation regardless of its moral content and irrespective of its repugnancy with any other value system (Turner, 1985, p. 24).

The philosophical strand of positive law is identifiable in human rights treaties, declaration, and conventions in general, and child rights instruments and laws in particular. The existence of a litany of international and regional human rights treaties, conventions, and declarations codifying general and thematic human rights standards and articulating its enforcement mechanisms is credited to positive law.

Notwithstanding the affinity of positive law to the philosophical framework of modern child rights instruments, it has been criticized for propagating the force of law over and above human morals and dignity. It has also been criticized for creating the legal platform for obnoxious regimes insensitive to human rights in general and child rights in particular, such as the Nazi regime, the apartheid rule in South Africa, and suppressive military dictatorships in Africa (Leiter, 2003; Goldsworthy, 1990). According to Dworkin, positive law has been criticized for lending credence to immoral and obnoxious laws and most times is undeserving of its title as "law" (Dworkin, 1977, 1986; Finnis, 2000, p. 1597).

Regardless of the intrinsic merit of the anti-positivist argument, the enablers of positive law are in consonance with modern day national and inter-state legal architecture whereby international, regional, and national parliaments make binding laws on contemporary and emerging issues. Noting that certain norms incompatible with the value system of the citizenry may be smuggled legislatively under the guise of positive law, the antidote to the promulgation of immoral or unjust laws on the altar of positive law is found in the prevailing model of informed public participation.

Under this process, citizens through their elected representatives and member states of the international community through their designated representatives are expected to oversee the promulgation of national legislation, international or regional treaties, or conventions that are in tune with the unifying value system of the country or international community. With the active and informed participation of the citizenry in the process of positive law, the likelihood of the promulgation or adoption of democratic laws at variance with the morality and values of the majority of the citizenry is relatively farfetched.

Positive law is certainly an indispensable tool in modern day efforts to promote and protect child rights. The fact that it allows a certain degree of flexibility in meeting with evolving rights is one of the strengths of positive law. One result of the inherent elasticity of positive law is the fact that child rights which a few decades ago were not articulated as distinct human rights are today legislated internationally, regionally, and nationally as discrete rights for specific categories of rights holders. ${ }^{2}$

\footnotetext{
${ }^{2}$ For instance and outside the specific boundaries of child rights, gay and lesbian rights which were unknown and maybe unthinkable a few decades ago are today classes of rights among others that are protected contemporarily through the elastic instrumentality of positive law.
} 


\section{Other Philosophical Foundations}

There are other philosophical foundations that differ from the postulations of natural law and positive law. One of them is the sociological jurisprudence, which stresses the social purpose of law and underlines the fact that law should be aligned with evolving social conditions (Gardner, 1961). According to Gardner (1961), the forerunner of sociological jurisprudence is Montesquieu who expounded the theory that natural rights are nothing more than legally protected social interests and recognized only insofar as aiding in securing the welfare of the society. In contrast to legal positivism which focuses on law in books, sociological jurisprudence defines law as a "matrix of relationships" and shifts the focus of attention to the study of the "living law" or "law in everyday life" (Edward, 1972, p. 999). It considers the latter as the "true law", and consequently, permits the abdication of any law in force, where such a law was, in the opinion of the court, contradictory to the "living law" (Edward, 1972, p. 999).

Claiming that every rule of law owes its origin to some predicated motive, this school argues that the purpose of law is to secure the conditions of social life as determined by the social order of the "time and place" (Round, 1912, p. 489). Sociological jurisprudence does not specifically allude to child rights and may be construed to deny any universal body of legal rules or institutions. It also subsumes individual interests to social interests and classifies individual rights as means of the society to realize its social ends (Westley, 1970). Postulating that law is relative to the civilization of the "time and place", sociological jurisprudence may be deemed to be compatible with child rights as an evolving trend in human rights. This is because the mission of the law under the sociological perspective is the advancement of civilization and changing with changed conditions (Canan, 1989). Since human rights accentuate existing values of civilization, child rights under the sociological perspective are arguably adapted to further the ideals of human dignity.

On the other hand, another philosophical foundation of law in general and human rights in particular is Marxism. It is the critical lens for challenging the wisdom of liberal legal thought and construes law as an instrument through which the capitalist class imposes and perpetuates its will (Hunt, 2010; Mojab, 2006). Marxism focuses on the nature of human beings and shares borders with natural law theory. It is, however, distinguishable from natural law theory on the grounds that it regards rights accruable to "citizens" which includes children as not emanating from a divine nature, but as "species-being” (Parent, 1974, p. 149; Marx, 2000).

Expounded by Karl Marx, this theory of human rights law like other theories did not treat children as a distinct class of rights holders. Preoccupied with the emancipation of the common man and by way of emphasis "common children", Marxism implies that the essence of a "person" which supposedly includes a child is to apply one's potential to the fullest and greatest satisfaction of one’s needs (Corrington, 2002, p. 747; Nielsen, 1987, p. 295). This theory espouses concepts, such as "law”, "justice”, "morality”, "freedom”, and "democracy" as the coefficients of the material conditions and social circumstances of the people in general and by extension children in particular (Corrington, 2002, p. 747; Nielsen, 1987, p. 295).

In opposition to the fundamental principles of capitalism, Marxism according to Mendus conceives a classless and anti-individualistic society facilitated by the state of social collectivity (Mendus, 1995; Kolakowski, 1983). Marxist appeal to child rights presupposes an ideology of possessiveness in the sense that when child rights are asserted as claims against the state, the assumption is that there is an endemic tension between the interest of the state and the interest of children. At variance with modern day capitalism and as a 
denial to an idealistic society, Marxist philosophy was popular in several countries until it was destabilized by the collapse of communism in Eastern Europe.

Whereas Marxism recognizes the competence of the international community to establish transnational human rights, including child rights norms, it subjects the application and implementation of these norms to exclusive domestic jurisdiction. This may account for one of the reasons why governments often on grounds of national sovereignty justify why each country should be free to interpret human rights as it pleases because what is good for the species-being is to be determined by respective states and not a communal decision of the international community (Shestack, 1998).

Another strand of the philosophical foundation of human rights is legal realism. The increase in the understanding of people and of their different cultures through the evolution of natural and social sciences gave rise to the realist conception of human rights and by extension child rights. According to White (1972; 1973), this philosophical school, while departing from abstract and analytical types of jurisprudence, contextualizes behavioral dimensions of law and society. Its distinctive feature in the conception of child rights lies in the fact that "it underscores the just equilibrium of interest among competing moral sentiments and in the context of social process identifies the empirical components of human rights system” (Lauren, 2011, p. 10; Afshari, 2007, p. 1).

There are numerous approaches to, and several leading philosophers of the realist theory of human rights and by extension child rights. According to James, the birth of the realist conception of child rights is anchored in the pragmatic principle that "the essence of good is simply to satisfy demand" (James, 1975, p. 185; Appelbaum, 1995). Without distinctly elaborating on child rights, he argued that the realist approach has an affinity with the development of contemporary human rights architecture which is stretching beyond classical civil and political rights, to economic, social, and cultural rights. Although the realist conception of rights takes into consideration the realities of surrounding social processes of result-mindedness and process-mindedness, Llewellyn (1962) observes that it is weak because when juxtaposed with the realities of the contemporary world, its premise is flawed due to the inconsistencies of its normative conclusion that rights are derived from interest.

Another philosophical foundation of human rights is utilitarianism. The contribution of this philosophical foundation to the discourse of human rights in general and child rights in particular is its focus on distributive rather than individualized happiness (Kamp, 1996). Utilitarianism presupposes that the rightness or otherwise of an action is a function of whether it precipitates the greatest happiness for the majority. Contrary to natural rights theory, utilitarianism predicates every human judgment on the arithmetic of pleasure versus pain of not just an individual but a group of individuals (Kamp, 1996). As such, the scorecard of the government is not how well it performed in protecting abstract individual rights including those of children but how well it advanced collective rights and ensured the greatest happiness for the greatest number (Freeman, 2011).

Langlois (2009, p. 990) quoted the "anarchical fallacies” of Bentham criticizing natural rights as rhetorical nonsense and argued that they are abstract metaphysical phenomena stemming from an unreal world. He categorized the rights of men as protective of the upper class citizen, as precipitating the capitalist domination by the wealthy and clogging the achievement of equality and well-being of the collective. Bentham's underlying communal preference principle, in Langlois' view, has been criticized for arbitrarily reducing the rightness of an action merely to the arithmetic of individual versus communal benefits. In the contemporary child rights regime, the geometry of Bentham's happiness theory of classical utilitarianism is inapplicable to the promotion and protection of child rights which is focused on an individual child. 
Over time and based on the weaknesses of Bentham's "happiness theory of the majority", the utilitarian theory was reformed to guide the conduct of government not on the basis of pleasure or happiness, but as a reflection of maximum satisfaction and minimum frustration of wants and preferences (Shestack, 1998, p. 214). Even with the readjustment of utilitarian theory from pleasure and happiness to economic decision-making, Rawls (1999) contended that it is still unable to plug the conceptual and practical gaps inherent in the formulation of the theory.

Juxtaposing the economic decision-making theory of reformed utilitarianism to present-day human rights realities in general and child rights in particular, utilitarianism is insensitive to children's individual autonomy and equality. Utilitarian maximization of aggregate desires or general welfare vis-à-vis individual satisfaction is inherently a weak option for the promotion and protection of child rights because, whilst it treats people as equals, it did not disaggregate "persons” to expressly include children (Baxi, 1998, p. 125; Shelton, 2002, p. 273).

\section{Inclusive Legal Positivism}

From the analysis of the foregoing philosophical foundations of human rights in general and child rights in particular, it is clear that there are different and somewhat conflicting philosophical lenses for viewing child rights. It is also irrefutable that there are inherent weaknesses in these individual philosophical foundations. As such this paper, akin to Coleman and Leiter's (2010) postulation, proposed a paradigm that it calls inclusive legal positivism. This hybrid philosophical foundation postulates that while moral principles can be explained by the rule of recognition, the legality of moral norms is not a function of their morality but of their validity under a rule of recognition (Coleman \& Leiter, 2010).

This strand of philosophical foundation of human rights in general and child rights in particular is inclusive because it combines the complementary and mutually reinforcing strengths of natural law and positive law philosophies. A blend of these two philosophies and resultant effects resonates with the realities of present day promotion and protection of child rights and is in tandem with contemporary child rights treaties, convention, legislation, etc.

The strength of inclusive legal positivism in the context of child rights is that while natural law's philosophical strand postulates that child rights accrue to people of a specific age because of their membership in the human race, the legal positivist philosophical strand situates child rights within the parameters of what is prescribed by law. Inclusive legal positivism exhibits and corroborates in child rights the double-barreled effects of natural law and positive law. This is because while natural law emphasizes the inherent dignity, vulnerability, and mitigated culpability of children on the basis of their membership of a distinct class of the human race, the positive law expediency is evident in the fact that child rights is what the law has promulgated it to be. As such, the confluence of natural law and positive law in the protection of child rights under inclusive legal positivism manifest in the positive promulgation of moral norms in favor of children.

Where morality is codified into law, it accumulates the individual strengths of natural law and positive law to provide compelling reasons for citizens to demand their rights and for government to implement the rights. According to Coleman and Leiter (2010, p. 228), and in line with their "incorporationism and legality argument", for a law to be authoritative, it must provide citizens with a reason to act that would have otherwise not been available without codification. It is only when moral rights that are essential to the enjoyment of child rights are prescribed as law, could such moral rights have the ability to improve the well-being of children that lay claim to them. 
Inclusive legal positivism is in line with the United Nations conception of child rights as entitlements codified in international human rights treaties and covenants. The preamble of the Universal Declaration of Human Rights alludes to the point that:

The General Assembly proclaims the Universal Declaration of Human Rights as a common standard of achievement for all peoples and all nations, to the end that every individual and every organ of society, keeping this Declaration constantly in mind, shall strive by teaching and education to promote respect for these rights and freedoms and by progressive measures, national and international, to secure their universal and effective recognition and observance, both among the peoples of Member States themselves and among the people of territories under their jurisdiction.

Inclusive legal positivism postulated in this paper may be attacked by ardent protagonists of natural law due to the fact that there is already an ongoing debate regarding the status of human rights or child rights claims prior to legislation. For instance, Dworkin $(1986 ; 1997)$ objects to the positivist's attempt to incorporate morality into law through the rule of recognition because a rule of recognition that includes reference to moral principles will violate the separability theory of positivism.

Conversely, the question is whether legislative codification of child rights through treaties, conventions, or national laws is the only process through which moral or any other claims are elevated to the status of child rights. Put differently, could child rights be guaranteed and protected in a country without enabling legislation? In response to these hypothetical questions and in justification of the philosophical foundation of inclusive legal positivism, suffice it to state firstly that child rights accrue to children by the simple fact of their age and their membership in the human race. Secondly, child rights claims could and do exist in isolation of the law, are not exclusively granted by law and do not necessarily require legislation to be effective.

Although child rights are capable of existing in isolation of the law, accruable to children with or without specific legislation, the promotion, and protection of child rights require law for vivid description of the rights and for their enforcement in the event of imminent threat or breach of the right. The promulgation of child specific and other human rights legislation combines the tripartite complements of legality, authority, and morality to make rights enforceable. Conceding that "the force of law" is very important in holding states accountable for respecting child rights, regional and international instruments may not adequately guarantee the observance of child rights unless the proposed enforceable rights connect with the inherent dignity of humanity. As such, the codification of child rights instruments, treaties, conventions, or legislation whether at the international or national level that penetrates beyond the legal code and reflects society's values is inevitable in making child rights protection effective (Marsh \& Payne, 2007).

Alluding to this postulation is the theory of "consensus" elaborated by Donnelly to the effect that human rights in the contemporary world are unanimously agreed moral obligations cast as universal standards, equipped with a distinctive cross cultural consensus and codified as human rights (Donnelly, 1984; Buergenthal, 1997). While human rights may exist devoid of legislation and may be protected with or without a legal framework, in the contemporary world, the interest in protecting and promoting child rights is better served if such rights are codified into law via treaties, conventions, national constitutions, or other Acts of Parliament. This accounts for the reason why present day child rights are legislatively depicted international, regionally, and nationally as binding law.

The effects of the inclusive legal positivism as a philosophical foundation of child rights reinforces as binding and enforceable law what ordinarily would have been mere ethical and moral claims. Therefore, unless moral values are codified into binding law, child rights may imperceptibly degenerate into empty rhetoric. On 
the basis of inclusive legal positivism, child rights are defined as a set of legally prescribed moral entitlements inherent equally in every child by virtue of their age and membership in the human race. It is immediately enforceable or progressively realizable through the legislative directives of designated national, regional, or international institutions.

\section{Normative Foundation of Child Rights}

Following the ill effects of fragmentation, inter-religious and inter-ethnic violence in the 20th century, states were obliged to commit to guaranteeing to their minorities certain collective rights and the abolition of religious and civil disabilities as a condition precedent to joining the "family of nations" (Mazower, 2004, p. 379; Benhabib, 2009, p. 691). The then "family of nations" was regulated by the League of Nations established to oversee international protection of rights of racial and religious minorities. Strong confidence was reposed in the League of Nations to amongst other things oversee international protection of minority rights. Incidentally, the operations of the League of Nations resulted in halfhearted support for racial equality and minority rights.

According to Mazower (2004), the League of Nations was also inhibited from commenting on racial segregation in the USA or criticizing the English treatment of Catholics of Chinese origin in Liverpool or the Nazi treatment of German Jews. Although the Covenant of the League of Nations is not strictly a human rights instrument and did not mention human rights or child rights in any of its 26 articles, it did make reference to children in two articles in relation to maintaining fair and humane conditions of labour (Pedersen, 2007) ${ }^{3}$, and with regard to supervision of execution of agreements in relation to trafficking of children (Goodrich, 1947; Northedge, 1986). ${ }^{4}$ The ensuing weakness of the League of Nations, the incidental loss of confidence, and total distrust of the effectiveness of its protection mechanism under international law among other intervening steps culminated in the demise of the League and the signing of the United Nations Charter by 26 member states in January $1942 .^{5}$

\section{United Nations Charter}

The present day prominence attached to human rights culminated after the Second World War in a strong reaction to the war-time atrocities (Hadjor, 1998; Cingranelli \& Richards, 1999). Although international law recognized some form of international human rights protection prior to the entry into force of the United Nations Charter, the normative foundation of modern international human rights law and by extension the institutionalization of child rights was consolidated with the adoption of the United Nations Charter in 1945 (Buergenthal, 1997; Stettinius, 1946; Cohen, 1949). Under the Charter, the willingness to commit to the defense of human rights within and outside the borders of member states was highlighted.

The Charter was also unprecedented in its articulation of human rights both in its preamble and its main body, thus making it one of the normative pillars of human rights and by extension child rights. Although the

\footnotetext{
3 Article 23(a): The Covenant of the League of Nations, signed 28 June 1919 at the Paris Peace Conference and entered into force on 10 January 1920.

${ }^{4}$ League of Nations, Covenant of the League of Nations, 28 April 1919. Article 23(c).

${ }^{5}$ The original twenty-six signatories were: the United States of America, the United Kingdom of Great Britain and Northern Ireland, the Union of Soviet Socialist Republics, China, Australia, Belgium, Canada, Costa Rica, Cuba, Czechoslovakia, Dominican Republic, El Salvador, Greece, Guatemala, Haiti, Honduras, India, Luxembourg, the Netherlands, New Zealand, Nicaragua, Norway, Panama, Poland, Union of South Africa, and Yugoslavia.
} 
UN Charter is not a child specific instrument and does not expressly mention children as holders of rights, it makes reference to human rights in its preamble and six other articles which, by extrapolation, can be seen to obviously relate to children (Fassbender, 1998). ${ }^{6}$ The then member states of the United Nations pledged not only to adhere to the principles contained in the Atlantic Charter, but also to preserve human rights and justice within their respective territories. Article 1(3) of the UN Charter recognizes that one of the purposes of the United Nations is international cooperation in solving various international problems, including humanitarian problems, and in promoting and encouraging respect for human rights and fundamental freedoms for all without distinction, such as race, sex, language, or religion.

The United Nations General Assembly in line with the dictates of the Charter affirms that peace and security, development and human rights are the pillars of the United Nations system and the foundations for collective security and well-being. It also recognizes that development, peace and security, and human rights are interlinked and mutually reinforcing. ${ }^{7}$ The Charter also assigns to member states the responsibility for promoting "universal respect for and observance of human rights and fundamental freedoms for all without distinction as to race, language, or religion”.

Article 56 provides that all members pledge themselves to take joint and separate action in cooperation with the organization for the achievement of the purposes set forth in Article 55. Despite the inherent weaknesses of the Charter, particularly in relation to the non-binding nature of its provisions, Buergenthal (1997) argued that the Charter provides the legal authority for the codification of human rights that ensued in 1948 and thereafter.

\section{Universal Declaration of Human Rights}

The bedrock of human rights is the International Bill of Rights adopted by the United Nations General Assembly and which includes the Universal Declaration of Human Rights (UDHR) (Glendon, 2002; Matt, 2011). ${ }^{8}$ UDHR is one of the founding documents of human rights law and is a non-binding declaration adopted in 1948 by the United Nations General Assembly (Cronin-Furman, 2010). As one of the greatest aspirational documents and corner-stone of human history meant to guide virtually all human rights, the UDHR urges member states to promote a number of civil, economic, and social rights (Li-ann, 2009). An-Na'im and Henkin (2000) postulated that the UDHR is the platform on which other human rights mechanisms are constructed, and held out human rights as "a common standard of achievement for all peoples and all nations" (Morsink, 1999). ${ }^{9}$

While the UDHR did not articulate any child-specific human rights provision, a deductive reading of the broad spectrum of rights guaranteed in the Declaration disposes it as one of the strongest normative frameworks for the protection of child rights. As "a first step in a great revolutionary process", the UDHR was intended not to be a binding legal document but instead a declaration of basic principles of human rights and freedoms (Cronin-Furman, 2010, p. 175). According to the former Secretary-General of the United Nations, Mr. Kofi A Annan, the principles enshrined in the Universal Declaration are the yardstick by which we measure progress. They lie at the heart of all that the United Nations aspire to achieve.... Human rights belong not to a chosen few,

\footnotetext{
${ }^{6}$ UN, Charter of the United Nations, 24 October 1945. Articles 1(3); 13(1)(b); 55(c); 62(2); 68; 76(c).

7 United Nations General Assembly, Resolution A/RES/60/251 of April 2006.

${ }^{8}$ UN General Assembly, Universal Declaration of Human Rights, 10 December 1948.

${ }^{9}$ Universal Declaration of Human Rights, 10 December 1948.
} 
but to all. It is this universality that endows human rights with the power to cross any border and defy any force. ${ }^{10}$

The scope of the UDHR is very broad and inclusive. As a seminal instrument that inaugurated a new body of international human rights law, the UDHR has not been eclipsed by the subsequent elaboration of its norms by new treaties. On the contrary, the binding instruments promulgated internationally and as well as in the regional realms have only highlighted the wisdom of the norms contained in the UDHR. The operative paragraph of the opening words of the UDHR indicates overwhelmingly that the drafters of the Declaration thought themselves as directing their attention to all members of the human race. It states that:

Now therefore the General Assembly proclaims this Universal Declaration of Human Rights as a common standard of achievement for all peoples and all nations, to the end that every individual and every organ of society, keeping this declaration constantly in mind, shall strive by teaching and education to promote respect for these rights and freedoms and by progressive measures, national and international, to secure their universal and effective recognition and observance, both among the peoples of the Member States themselves and among the peoples of territories under their jurisdiction.

The UDHR also set out in its preamble the recognition "of the inherent dignity and of the equal and inalienable rights of all members of the human family as the foundation of freedom, justice, and peace in the world” (Waltz, 2001, p. 44; Bernstorff, 2008, p. 903). ${ }^{11}$ According to Alves (2000, p.478), it is an extraordinary statement in the history of mankind that codifies the "hopes of the oppressed, supplying authoritative language to the semantics of their claims". It also "offered a legislative basis for the political struggles for liberty and led national constitutions to transform the notion of citizen's rights into positive law” (Alves, 2000, p. 478).

Through the Declaration, the General Assembly reaffirms the inter-dependence and inter-connectedness of human rights and requested the preparation of a human rights covenant and a draft measure for its implementation as a matter of priority. It has been stated that the work of the Human Rights Commission, through the groundbreaking provisions of the Declaration was elaborated into two binding international covenants (Pace, 1998). The flip side of the UDHR, it has been noted, is the fact that the legal force of its provisions is neither sufficient to effectuate human rights nor does the content of its provisions accommodate any enforcement mechanism in the event of violation (Cronin-Furman, 2010).

\section{International Covenants}

In a bid to overcome the weaknesses of the UDHR and create a binding legal instrument, the United Nations Commission on Human Rights drafted a pair of binding covenants, the International Covenant on Civil and Political Rights (ICCPR) (Keith, 1999) ${ }^{12}$ and the International Covenant on Economic Social and Cultural Rights (ICESCR) (Craven, 1995). ${ }^{13}$ Having been both adopted in 1966, the ICESR details the basic civil and political rights of individuals and groups of individuals and the ICESCR commits state parties to granting socio-economic rights to individuals, including labor rights, right to health, education, and adequate standard of living.

The ICCPR and ICESCR together with the UDHR form the 'International Bill of Rights' and jointly precipitates the expansion of international human rights and child rights standards in the form of treaties, declarations, and conventions. In the context of child justice, Article 10(2)(b) of the ICCPR provides that

\footnotetext{
${ }^{10}$ Speech of the United Nations Secretary General , Kofi A. Annan on the 50th Anniversary of the Universal Declaration of Human Rights <http://www.un.org/News/Press/docs/1998/19981201.sgsm6815.html> accessed 13 January 2012.

${ }^{11}$ UN General Assembly, Universal Declaration of Human Rights, 10 December 1948.

12 UN General Assembly, International Covenant on Civil and Political Rights, 16 December 1966.

${ }^{13}$ UN General Assembly, International Covenant on Economic, Social, and Cultural Rights, 16 December 1966.
} 
children accused of being in conflict with the law shall be separated from adults and brought as speedily as possible for adjudication. Article 14 grants equality in the determination of a criminal change and other due process rights.

While the adoption of both the ICCPR and ICESCR did not generate as much global attention as did the UDHR, it has been argued that both covenants provide a seismic shift that furthered the notion of human rights from one of vague and non-enforceable provisions of the UDHR to a legally binding norm (Cronin-Furman, 2010). The ICCPR and the ICESCR guarantee a broad spectrum of rights to all individuals within the territory or under the jurisdiction of the state parties without discrimination (Carpenter, 2001). While the two covenants did not in actual fact provide expressly for child rights, the rights guaranteed to "all individuals" under both covenants deductively apply to children as human beings.

The character of the obligations undertaken by state parties differs from the ICCPR and ICESCR. Under the ICCPR, state parties undertake to respect and to ensure to all individuals within their territory the rights recognized in the covenant. On the other hand, the undertaking of state parties under the ICESCR is to take measures to the extent of available resources with a view to achieving progressively the realization of the rights recognized in the Covenant (Lallah, 1992). The difference in the articulation of these two covenants may have informed the implementation time frames and gaps between the two classes of rights, and may have been the reason why the ICCPR is immediately enforceable whereas the ICESCR is only progressively realizable.

While this paper will not delve into a detailed description of these two covenants and the working methods of the treaty bodies charged with overseeing their implementation, it is necessary to underline the fact that the elevation of human rights under these covenants as the "highest aspiration" of the common man and "common standard" equally applies to child rights.

\section{Child-Specific International Instruments}

As was the case with human rights in general, the post-World War II era consolidated the normative foundation of child rights. It triggered a paradigm shift that precipitated international, regional, and national legislation to accord children autonomous and distinct rights from those enjoyed by the rest of humanity (Denov, 2004). Whereas the International Bill of Rights contains guarantees also applicable to children, there was the need for an international legal framework dealing specifically with children's particular needs. It was in response to the apparent need for a legally binding instrument focusing exclusively on the specific needs of children that the CRC was adopted (Harris-Short, 2003; Dominic, 1991). ${ }^{14}$

The CRC thus became the first legally binding international instrument to exclusively focus on children and accommodate all classes of rights including the civil, cultural, economic, political, and social rights (Hammarberg, 1990). The CRC has developed into an essential worldwide legal tool and enunciated core principles for the protection of rights of the child in general and particularly those in conflict with the law. To encourage the prompt domestication of the CRC, Article 4 urges member states to take all appropriate legislative, administrative, and other measures for the implementation of the rights recognized in the convention.

Prior to the adoption of the CRC and the setting of non-negotiable standards and obligations, one of the first international legal instruments to comprehensively detail child rights in the particular context of the administration of child justice is the Standard Minimum Rules for the Administration of Juvenile Justice,

${ }^{14}$ UN General Assembly, Convention on the Rights of the Child, 20 November 1989. 
commonly known as the "Beijing Rules" (Kubota, 1989, p. 7). ${ }^{15}$ The normative gains of the CRC and the "Beijing Rules" were built upon with the adoption of the United Nations Rules for the Protection of Juveniles Deprived of their Liberty (Kilkelly, 2008). ${ }^{16}$ The purpose of the Rules is to uphold the rights and safety of children and promote their physical and mental well-being. Another international instrument that added to the normative fortress of child rights is the United Nations Guidelines for the Prevention of Juvenile Delinquency popularly called the "Riyadh Guidelines" (Muncie, 2005, p. 134). ${ }^{17}$

These Guidelines underline preventive policies as a way of facilitating successful socialization and integration of children and young persons. In addition, the Declaration of the Rights of the Child (Detrick, 1999), ${ }^{18}$ the World Summit for Children (Wheeler, 2006), ${ }^{19}$ and the United Nations General Assembly Special Session on Children, ${ }^{20}$ consolidated the normative foundation of child rights. Other relevant instruments for the promotion and protection of child rights include United Nations General Assembly Resolutions 2003/85, ${ }^{21}$ and $2004 / 47^{22}$ on the abduction of children and Security Council Resolution $1379^{23}$ and 1460 on Children in Armed Conflict. $^{24}$

At the regional level, the CRC has been widely ratified by member states of the United Nations including most African states. The mass ratification of the CRC in the African continent amongst other things influenced to a large extent the African human rights architecture. The contemporary normative architecture of Africa's regional human rights system has been attributed to the coming into force of the Constitutive Act of the Organization of African Unity (Odinkalu, 2002; Abass \& Baderin, 2002), culminating in the adoption of the African Charter on Human and Peoples Rights (ACHPR) in 1981 (Okere, 1984). ${ }^{25}$ The African Charter establishes a regional human rights framework in the continent.

Motivated also by the enthusiasm to define and establish child rights within the parameters of the African value system, the African Charter on the Rights and Welfare of the Child was adopted (Olowu, 2002). It regionalizes the contents of the CRC and interprets universal human rights in the light of the socio-economic realities and traditions of Africa. ${ }^{26}$ The ACRWC also provides for a separate justice system within which children in conflict with the law are adjudicated for rehabilitative purposes (Amanda, 2002). At the national level, the legal framework for child rights in Nigeria is embodied in the 1999 Constitution, the CRA, other national legislation, and indirectly through regional and international human rights instruments to which Nigeria is a state party.

\footnotetext{
${ }^{15}$ UN General Assembly, United Nations Standard Minimum Rules for the Administration of Juvenile Justice (The Beijing Rules) 29 November 1985.

${ }^{16}$ UN General Assembly, United Nations Rules for the Protection of Juveniles Deprived of Their Liberty, 2 April 1991.

17 UN General Assembly, United Nations Guidelines for the Prevention of Juvenile Delinquency (The Riyadh Guidelines), 14 December 1990.

${ }^{18}$ UN General Assembly Declaration on the Rights of the Child, 20 November 1959.

${ }^{19}$ UN General Assembly, 2005 World Summit Outcome, 24 October 2005.

${ }^{20}$ UN General Assembly, Follow-up to the United Nations Special Session on Children, 17 August 2004.

${ }^{21}$ UN Commission on Human Rights, Commission on Human Rights Resolution 2003/85: Abduction of Children in Africa, 25 April 2003.

${ }^{22}$ UN Commission on Human Rights, Commission on Human Rights Resolution 2004/47: Abduction of Children in Africa, 20 April 2004.

${ }^{23}$ UN Security Council, Security Council Resolution 1379 (2001) on the Protection of Children in Armed Conflicts, 20 November 2001.

${ }^{24}$ UN Security Council, Security Council Resolution 1460 (2003) on Children in Armed Conflict, 30 January 2003.

25 Organization of African Unity (OAU), African Charter on Human and Peoples' Rights (Banjul Charter), 27 June 1981.

26 Ibid.
} 


\section{Conclusion}

This paper examined more specifically the philosophical strands of natural law and legal positivism and cursorily, the other philosophical foundations. Based on the inherent weaknesses of natural law and legal positivism as stand-alone philosophies and bearing in mind their potential complementarity if their respective strengths are aggregated, this paper proposed a paradigm philosophy that is branded as "inclusive legal positivism". Construing child rights as those specific moral rights that inhere in children due to their age and vulnerability and which are normatively protected, this paper argued that the philosophical orientation of child rights is inclusive because it sums up the strengths of natural law and legal positivism in consonance with contemporary international and regional human rights frameworks.

\section{References}

Abass, A., \& Baderin, M. A. (2002). Towards effective collective security and human rights protection in Africa: An assessment of the Constitutive Act of the New African Union. Netherlands International Law Review, 49(1), 1-38.

Afshari, R. (2007). On historiography of human rights reflections on Paul Gordon Lauren's the evolution of international human rights: Visions seen. Human Rights Quarterly, 29(1), 1-67.

Alves, J. A. L. (2000). The declaration of human rights in post modernity. Human Rights Quarterly, 22(2), 478-500.

Amanda, L. (2002). Theoretical analysis of the reality of children's rights in Africa: An introduction to the African charter on the rights and welfare of the child. African Human Rights Law Journal, 2(1), 11-32.

An-Na'im, A. A., \& Henkin, L. (2000). Islam and human rights: Beyond the universality debate. American Society of International Law, 94, 95-103.

Appelbaum, S. (1995). William James pragmatism. New York, N.Y.: Dover Publications.

Baxi, U. (1998). Voices of suffering and future of human rights. Transnational Law and Contemporary Problems, 8(2), 125.

Beitz, C. R. (2001). Human rights as a common concern. USA: American Political Science Association.

Beitz, C. R. (2009). The idea of human rights. Oxford: Oxford University Press.

Benhabib, S. (2009). Claiming rights across borders: International human rights and democratic sovereignty. American Political Science Review, 103(4), 691-704.

Bernstorff, J. (2008). The changing fortunes of the universal declaration of human rights: Genesis and symbolic dimensions of the turn to rights in international law. European Journal of International Law, 19(5), 903-924.

Beyleveld, D., \& Brownsword, R. (1983). Law as a moral judgment vs law as the rules of the powerful. American Journal of Jurisprudence, 28(1), 79-117.

Binion, G. (1995). Human rights: A feminist perspective. Human Rights Quarterly, 17(3), 509.

Bix, B. (1993). Law, language, and legal determinacy. Oxford: Oxford University Press.

Bix, B. (1999). Positively positivism. Virginia Law Review, 85, 889-932.

Bix, B. (2000). On the dividing line between natural law theory and legal positivism. Notre Dame Law Review, 75, 1613-1624.

Bix, B. (2001). Natural law: The modern tradition. In J. L. Coleman and S. Shapiro (Eds.), Oxford handbook of jurisprudence and philosophy of law. Oxford: Oxford University Press.

Bix, B. (2003). Can theories of meaning and reference solve the problem of legal determinacy? Ratio Juris, 16(3), 281-295.

Bix, B. (2009). Jurisprudence: Theory and context (5th ed.). London: Sweet \& Maxwell.

Blackstone, W. (1978). Commentaries on the laws of England (Vol. 2). New York, N.Y.: Garland Publication.

Buergenthal, T. (1997). The normative and institutional evolution of international human rights. Human Rights Quarterly, 19(4), 703-723.

Bunch, C. (1990). Women’s rights as human rights: Toward a re-vision of human rights. Human Rights Quarterly, $12(4), 486$.

Burke, E. (2000). Reflection on the revolution of France. Manchester: Manchester University Press.

Canan, P. (1989). SLAPP from a sociological perspective. Pace Environmental Law Review, 7, 3-21.

Carpenter, K. D. A. (2001). International covenant on civil and political rights: A toothless tiger? North Carolina Journal of International Law and Commercial Regulation, 26, 1.

Cingranelli, D. L., \& Richards, D. L. (1999). Respect for human rights after the end of the Cold War. Journal of Peace Research, 36(5), 511-534. 
Cohen, B. V. (1949). Human rights under the United Nations Charter. Journal Law and Contemporary Problems, 14(3), $430-437$.

Coleman, J. L., \& Leiter, B. (2010). Legal positivism' in Dennis Patterson: A companion to philosophy of law and legal theory (2nd ed.). Oxford: Wiley-Blackwell.

Coleman, J. L. (1999). Reason and authority. In R. George (Ed.), The autonomy of law: Essay on legal positivism. Oxford: Oxford University Press.

Corrington, W. J. (2002). Generalities. Legal Studies Forum, 26, 747-765.

Craven, M. (1995). The international covenant on economic, social and cultural rights: A perspective on its development. Oxford: Clarendon Press.

Cronin-Furman, K. R. (2010). 60 years of the universal declaration of human rights: Towards an individual responsibility to protect. American University International Law Review, 25(1), 175-198.

Culver, K. (2001). Leaving the Hart-Dworkin debate. University of Toronto Law Journal, 51, 367.

Denov, M. S. (2004). Children's rights or rhetoric? Assessing Canada’s youth criminal justice act and its compliance with the UN convention on the rights of the child. International Journal of Children's Rights, 12, 1-24.

Detrick, S. (1999). A commentary on the United Nations convention on the rights of the child. Hague: Martinus Nijhoff Publishers.

Doernberg, D. L. (1985). We the people: John Locke, collective constitutional rights, and standing to challenge government action. California Law Review, 73, 52-118.

Dominic, M. (1991). The United Nations convention on the rights of the child. International Journal of Law, Policy and the Family, 5(2), 132-169.

Donnelly, J. (1984). Cultural relativism and universal human rights. Human Rights Quarterly, 6(4), 400-419.

Dworkin, R. (1977). Taking rights seriously. Cambridge: Harvard University Press.

Dworkin, R. (1978). Taking rights seriously. Library of Congress Cataloging-in-Publication Data.

Dworkin, R. (1986). Law's empire. Cambridge: Harvard University Press.

Dworkin, R. (1997). In praise of theory. Arizona State Law Journal, 29, 353.

Dworkin, R. (2006). Justice in robes. Library of Congress Cataloging-in-Publication Data.

Dyson, R. W. (2002). Aquinas political writings. Cambridge: Cambridge University Press.

Edward. W. G. (1972). From sociological jurisprudence to realism: Jurisprudence and social change in early twentieth-century America. Virginia Law Review, 58, 999-1028.

Fassbender, B. (1998). The United Nations Charter as the constitution of the international community. Columbia Journal of Transitional Law, 36(3), 529-620.

Finnis, J. (1988). Aquinas: Moral, political, and legal theory. Oxford: Oxford University Press.

Finnis, J. (2000). On the incoherence of legal positivism. Notre Dame Law Review, 75, 1597.

Finnis, J. (2007). Grounds of law and legal theory: A response. Legal Theory, 13, 315.

Finnis, J. (2011). Natural law and natural rights (2nd ed.). Oxford: Oxford University Press.

Freeman, M. (1994). The philosophical foundations of human rights. Human Rights Quarterly, 16(3), 491-514.

Freeman, M. (2011). Human rights: An interdisciplinary approach (2nd ed.). Malden, MA: Polity Press.

Fuller, L. L. (1958). Positivism and fidelity to law: A response to Professor Hart. Harvard Law Review, 71(4), 630-672.

Fuller, L. L. (1969). The morality of law. New Haven: Yale University Press.

Gardner, J. (2001). Legal positivism: 5 1⁄2 myths. American Journal of Jurisprudence, 46(1), 199-227.

Gardner, J. A. (1961). The sociological jurisprudence of roscoe pound. Villanova Law Review, 7(1). Retrieved from http://digitalcommons.law.villanova.edu/vlr/vol7/iss1/1

Glendon, M. A. (2002). A world made new: Eleanor Roosevelt and the universal declaration of human rights. New York, N.Y.: Random House Publishing Group.

Goldsworthy, J. D. (1990). Self-destruction of legal positivism. Oxford Journal of Legal Studies, 10(4), 449-486.

Goodrich, L. M. (1947). From league of nations to United Nations. International Organization, 1(1), 3-21.

Green, L. (2008). Positivism and the inseparability of law and morales. New York University Law Review, 83, 1035-1058.

Hadjor, K. B. (1998). Whose human rights? Journal of Asian and African Studies, 33(4), 359-368.

Hammarberg, T. (1990). The U.N convention on the rights of the child and how to make it work. Human Rights Quarterly, 12(1), 97.

Hampton, J. (1986). Hobbes and the social contract tradition. Cambridge: Cambridge University Press. 
Harris-Short, S. (2003). International human rights law: Imperialist, inept and ineffective? Cultural relativism and the UN Convention on the rights of the child. Human Rights Quarterly, 25(1), 130-181.

Hart, H. L. A. (1983). Essays on jurisprudence and philosophy. Oxford: Oxford University Press.

Hart, H. L. A. (2012). The concept of law. Oxford: Oxford University Press.

Hunt, A. (2010). The object of Marxist theory of law' in Dennis Patterson: A companion to philosophy of law and legal theory (2nd ed.). London: Wiley-Blackwell.

James, W. (1975). Pragmatism. Cambridge: Harvard University Press.

Kamp, A. (1996). Between-the-wars social thought: Karl Llewellyn, legal realism and the uniform commercial code in context. Albany Law Review, 59, 325-397.

Keith, L. C. (1999). The United Nations international covenant on civil and political rights: Does it make a difference in human rights behavior? Journal of Peace Research, 13, 195.

Kilkelly, U. (2008). Youth justice and children's rights: Measuring compliance with international standards. London: Sage Publication.

Kolakowski, L. (1983). Marxism and human rights. Daedalus, 112(4), 81-92.

Kubota, Y. (1989). The protection of children's rights and the United Nations. Nordic Journal of International Law, 58(1), 7-23.

Lallah, R. (1992). Notes on the international covenant on civil and political rights and some of its case law. Common Wealth Law Bulletin, 18, 1258.

Langlois, A. (2002). Human rights: The globalization and fragmentation of moral discourse. Review of International Studies, 28(3), 479-496.

Langlois, A. J. (2009). Normative and theoretical foundation of human rights. Human Rights: Politics and Practice, 25(4), 990-1019.

Lauren, P. (2011). The evolution of international human rights: Visions seen (3nd ed.). Pennsylvania: University of Pennsylvania Press.

Leiter, B. (2001). Legal realism and legal positivism reconsidered. Ethics, 111(2), 278-301.

Leiter, B. (2003). Beyond the Hart/Dworkin debate: The methodology problem in jurisprudence. American Journal of Jurisprudence, 48(1), 17-51.

Lenz, J. W. (1956). Locke’s essays on the law of nature. Philosophy and Phenomenological Research, 17(1), 105-113.

Leyden, W. (1956). John Locke and natural law. Philosophy, 31, 23-35.

Li-ann, T. (2009). The historical origins and contemporary evolution of international human rights law. Singapore Academy of Law Journal, 21(1), 261-292.

Lisska, A. J. (1996). Aquinas's theory of natural law: An analytic reconstruction. Oxford: Oxford University Press.

Llewellyn, K. (1962). Jurisprudence: Realism in theory and practice. Chicago: University of Chicago Press.

Locke, J. (1988). Two treatises of government (P. Lasslet Ed.). Cambridge: Cambridge University Press.

Mahoney, J. (2007). The challenge of human rights: Origin, development, and significance. Oxford: Blackwell Publishers.

Marsh, C., \& Payne, D. P. (2007). The globalization of human rights and the socialization of human rights norms. Brigham Young University Law Review, 3, 665-687.

Marx, K. (2000). Selected writings (D. McLellan Ed.). Oxford: Oxford University Press.

Matt, D. (2011). Universal declaration of human rights. New York, N.Y.: Springer.

Mazower, M. (2004). The strange triumph of human rights, 1933-1950. The Historical Journal, 47(2), 379-398.

Mendus, S. (1995). Human rights in political theory. Political Studies, 43(1), 10-24.

Mojab, S. (2006). In the quagmires of ethnicity: A Marxist critique of liberal “exit strategies”. Journal of Ethnicities, 6(3), 341-361.

Moore, M. S. (1985). A natural law theory of interpretation. Southern California Law Review, 58, 277.

Moore, M. S. (2011). Justifying the natural law school on constitutional interpretation. Fordham Law Review, 69, 2087.

Morsink, J. (1999). The universal declaration of human rights: Origins, drafting and intent. Philadelphia: University of Pennsylvania Press.

Muncie, J. (2005). The globalization of crime control—The case of youth and juvenile justice: Neo-liberalism, policy convergence and international conventions. Theoretical Criminology, 9, 134.

Murphy, M. C. (2001). Natural law and practical rationality. Cambridge: Cambridge University Press.

Murphy, M. C. (2003). Natural law jurisprudence. Legal Theory, 9(4), 241-267.

Murphy, M. C. (2006). Natural law in jurisprudence and politics. Cambridge: Cambridge University Press. 
Nielsen, K. (1987). Marxism and the moral point of view. American Philosophical Quarterly, 24(4), 295-306.

Nolan, D. R. (1976). Sir William Blackstone and the new American republic: A study of intellectual impact. New York University Law Review, 51, 731-768.

Northedge, F. S. (1986). The league of nations: Its life and times, 1920-1946. Leicester: Leicester University Press.

Odinkalu, C. A. (2002). Africa's regional human rights system: Recent developments and jurisprudence. Human Rights Law Review, 2(1), 99-106.

Okere, B. O. (1984). The protection of human rights in Africa and the African Charter on human and peoples' rights: A comparative analysis with the European and American systems. Human Rights Quarterly, 6(2), 141-159.

Olowu, D. (2002). Protecting children's rights in Africa: A critique of the African Charter on the rights and the welfare of the child. International Journal of Child Rights, 10(2), 127-136.

Pace, J. P. (1998). The development of human rights law in the United Nations, Its control and monitoring machinery. International Social Science Journal, 50, 499.

Parent, W. A. (1974). Some recent work on the concept of liberty. American Philosophical Quarterly, 11(3), 149-167.

Pedersen, S. (2007). Back to the league of nations. The American Historical Review, 112(4), 1091-1117.

Rawls, J. A. (1999). Theory of justice. Cambridge: Harvard University Press.

Raz, J. (1979). The authority of law. Oxford: Clarendon Press.

Raz, J. (1985). Authority, law and morality. The Monist, 68(3), 295-324.

Raz, J. (2006). The problem of authority: Revisiting the service conception. Minnesota Law Review, 90, 1003-1044.

Round, R. (1912). The scope and purpose of sociological jurisprudence [Concluded] III: Sociological jurisprudence. Harvard Law Review, 25, 489-516.

Schauer, F. (2011). Positivism before Hart. Canadian Journal of Law and Jurisprudence, 24(2), 455-471.

Shelton, D. (2002). Protecting human rights in a global world. Boston College International and Comparative Law Review, 25, 273.

Shestack, J. (1998). The philosophic foundations of human rights. Human Rights Quarterly, 20(2), 201-234.

Spaak, T. (2003). Legal positivism, law's normativity and the normative force of legal justification. Ratio Juris, 16(4), $469-485$.

Stettinius, E. R. (1946). Human rights in the United Nations Charter. The Annals of the American Academy of Political and Social Science, 243(1), 8-10.

Tamanaha, B. Z. (2007). Contemporary relevance of legal positivism. Australian Journal of Legal Philosophy, 32, 1-38.

Tully, J. (1996). An approach to political philosophy: Locke in contexts. Dialogue: Canadian Philosophical Review, $35(4), 825$.

Turner, J. H. (1985). In defense of positivism. Sociological Theory, 3(2), 24-30.

Waldron, J. (1989). John Locke: Social contract versus political anthropology. The Review of Politics, 51(1), 3-28.

Waltz, S. E. (2001). Universalizing human rights: The role of small states in the construction of the universal declaration of human rights. Human Rights Quarterly, 23, 44-72.

Weinreb, L. L. (1987). Natural law and justice. Library of Congress Cataloging-in-Publication Data.

Weinrib, E. J. (1988). Legal formalism: On the immanent rationality of law. Yale Law Journal, 97, 949.

Weinrib, E. J. (2012). The idea of private law. Oxford: Oxford University Press.

Westley, W. A. (1970). Violence and the police: A sociological study of law, custom, and morality. Cambridge, MA: Mit Press.

Wheeler, N. J. (2006). Victory for common humanity: The responsibility to protect after the 2005 world summit. Journal of International Law and International Relations, 2(1), 95-107.

White, G. E. (1972). From sociological jurisprudence to realism: Jurisprudence of social change in early twentieth century America. Virginia Law Review, 58, 999.

White, G. E. (1973). The evolution of reasoned elaboration: Jurisprudential criticism and social change. Virginia Law Review, 59, 279. 